\title{
7 \\ Deep Diversity: Charles Taylor and the Politics of Federalism
}

Although this Chapter will Center on a concept introduced by Charles Taylor, I shall bring to bear upon it writings by a number of other Canadian scholars. Taylor-who also speaks as a political figure-is an advocate of special status for Francophones and the province of Quebec, much as his younger Canadian colleague and critic Will Kymlicka is an advocate of "special rights" and special status for aboriginal peoples. Both are part of the Anglo-European tradition and, in dealing with the Canadian situation, they address work by others in the same tradition. For instance, while the bibliography of Kymlicka's Liberalism, Community, and Culture lists several works by aboriginal writers, he makes few references to their positions save in notes. ${ }^{1}$ Similarly, Taylor maintains that the constitutional changes he proposes in Reconciling the Solitudes will "do justice to [Canada's] aboriginal populations" as well as to Quebecers. ${ }^{2}$ Yet he fails to take into account any writings by aboriginals or official statements issued by aboriginal organizations. As Menno Boldt, J. Anthony Long, and Leroy Little Bear charge in the Preface to their anthology, The Quest for Justice: Aboriginal Peoples and Aboriginal Rights, "the aboriginal perspective is largely missing from published works on issues affecting aboriginal peoples."3 One Euro-Canadian thinker who does take aboriginal writings and documents into account is Michael Asch, an anthropologist whose book Home and Native Land: Aboriginal Rights and the Canadian Constitution is a penetrating essay in applied political philosophy. ${ }^{4}$ In what follows, I shall try to bring material from this book and from The Quest for Justice to bear on Taylor's proposal and on its consequences for aboriginal communities as well as for Quebec. 
It is common, in some parts of the world, to refer to a culturally and linguistically distinct population, particularly one that is identified with a particular geographic location, as a nation. Using the term in this sense, we can think of Francophone Quebecers as a nation, as are the aboriginal peoples, the First Nations, of Canada. English Canada, while culturally and historically distinct, has come to include many immigrant groups, who have largely assimilated English culture, and English speakers tend to think of themselves as Canadian rather than as English. While focusing on the French, Taylor, instead of advocating independence, searches for a way to allow all the diverse nations a substantial measure of selfgovernment while still preserving Canadian unity. Despite the fact that his view of Canada as basically binational and bilingual continually surfaces, he gives us a pluralist solution. Rather than dwell on his dualist bias, I want to concentrate on this proposal, which turns out to be consonant with Asch's approach and with the view that seems to predominate in the aboriginal nations. Asch quotes Dr. David Ahenakew, national chief of the Assembly of First Nations, ${ }^{5}$ addressing the Constitutional Conference of First Ministers in 1983: "We recognize that it is the view of many that the word 'sovereignty' defines an extreme at one end of a list of options available and the word 'assimilation' describes an extreme on the opposite end. We say there is a middle ground" (HNL 89). The complex type of federalism that Taylor advocates, incorporating the principle he calls "deep diversity," is located in that middle ground.

Boldt and Long, in the concluding paper in The Quest for Justice, acknowledge that some indigenous peoples have "adopted the concept of sovereignty as the cornerstone of their aspirations." But they take this position to be mistaken, and point out that, historically, the European concept of sovereignty is "not relevant to their internal or external relationships." It was never "in the cultural apparatus of Indians" (TT 341, 342). ('Indian' is used by them as a generic name for the diverse aboriginal peoples.) "Prior to colonization, Indian tribes held an independent self-governing status best defined as 'nationhood,' not 'statehood' " (TT 340). Their own position, like Ahenakew's, is that "the acceptable model for a relationship between the federal government and 
Canada's Indians lies somewhere between assimilation and sovereignty" (TT 342).

In the same volume, Fred Plain defends the aboriginal right of "independence through ... self-government, our right to selfdetermination, ... to nationhood." 7 The right to self-determination is, first of all, the right of each indigenous nation "to develop its own traditions and culture-its own civilization." It is a right "to develop and grow under our own system, and our own system will flow from our own people, who," Plain says, "will develop our own constitution" (QJ 33). But he goes on to claim that "[o]ur Indian constitutions have every right to be recognized in any new Canadian constitution," implying that the independence and self-government sought by his people are to be within the Canadian federation (QJ 33). He reports that, in their declaration of 1977, the Nishawbe-Aski Commission "stressed that their objective was to see the full development of cultural, economic, spiritual, and political independence" (QJ 36). Speaking of what he holds to be the original right of the Nishawbe-Aski people to their own constitution, "the right to make their own laws and determine their own destiny through their own governing system," Plain states that their challenge to the Canadian constitution was based on the government's unwillingness to recognize this right. He goes on to speak of "the true aboriginal rights that must be recognized in any Canadian constitution."

Speaking for the Inuit people, Peter Ittinuar takes a strong position in favor of federalism: "The challenge we face is to insure the preservation of [our aboriginal] rights in the context of an evolving Canadian federalism. I suspect the Indian and Metis peoples see their struggle in much the same way." 8

What Taylor calls for is a more decentralized and more complicated federal system than that which presently obtains in Canada. He specifies that the "asymmetrical federalism" he is talking about "means special status for Quebec."9 But in fact the kind of "deep diversity" he recommends would confer special status on each constituent, including several new political entities that would be created. That is, each might have different powers, different spheres of autonomy. He would like to see Quebec retain all its current provincial powers, but other provinces might "opt for the centralization of several powers" and while some "coordination 
will occur through interprovincial agreements," in certain cases "it would be better to imagine a shared or concurrent jurisdiction" (RS 147). As Taylor puts it at one point, "to each province according to its tasks," the powers that would enable it "to cope with problems ... that other provinces do not have" (DV 180). But over and above the provinces, he recommends "the granting of certain powers of self-rule to aboriginal communities" (CR 148). Assuming that these communities are the national communities or tribes, this would mean creating a new level of political organization, neither provincial nor municipal and, in some cases, crossing provincial boundaries: "[O]ur arrangements have to accommodate the need for forms of self-government and self-management appropriate to the different First Nations. This may mean in practice allowing for a new form of jurisdiction in Canada, perhaps weaker than the provinces, but, unlike municipalities, not simply the creatures of another level of government" (DV 180).

The fundamental principle of this restructuring of the country is provision of a new basis for citizenship, reflecting the existence of diverse nations within the state. ${ }^{10}$ Rather than accepting the view of Canada at large as a multicultural mosaic, in which ethnic origin has the same weight and significance for everyone and assimilation is expected to be the norm, Taylor introduces the concept of what he calls "second-level" or "deep" diversity and suggests a restructuring of the Canadian polity based upon it. Unlike the "first-level" diversity of the conventional model, in which one is a citizen of a country simply as an individual, the "deep diversity" model recognizes the importance of national identity and the resistance of national communities to assimilation. The aboriginal peoples are established nations with a long history and insist upon their national status at least as strongly as does the Francophone population of Quebec. He proposes, therefore, that members of these communities hold citizenship in the state, not as independent individuals, but as and insofar as they belong to the subaltern nations. Those who identify as Canadians, including the descendants of immigrants and Indians who have opted for "enfranchisement" (termination of Indian status), would hold citizenship in the country directly. ${ }^{11}$

Giving special citizenship status to Indians, Inuit, and Metis is 
consistent with the aboriginal rights guaranteed by the Constitutional Act of 1982, rights that these peoples insist belong to them as nations rather than to their members as individuals. ${ }^{12}$ What is at stake is both the sense of identity and actual political status. "To build a country for everyone," Taylor contends,

Canada would have to allow for second-level or "deep" diversity, in which a plurality of ways of belonging would also be acknowledged and accepted. Someone of, say, Italian extraction in Toronto or Ukrainian extraction in Edmonton might indeed feel Canadian as a bearer of individual rights in a multicultural mosaic. His or her belonging would not "pass through" some other community, although the ethnic identity might be important to him or her in various ways. But this person might nevertheless accept that a Québécois, or a Cree, or a Déné might belong in a very different way, that these persons were Canadian through being members of their national communities. Reciprocally, the Québécois, Cree, or Déné would accept the perfect legitimacy of the "mosaic identity" [DV 183].

Reminding us of the important functions performed by a federal state-everything from defense and the provision of currency to regulating "regional equality and mutual self-help"-Taylor argues for its necessity and, hence, against political independence for the constituent nations, even Quebec. "Deep diversity," he holds, is "the only formula on which a united federal Canada can be built" (DV 183). And, looking beyond Canada, he writes, "Second, in many parts of the world today the degree and nature of the differences resemble those of Canada. . . . If a uniform model of citizenship fits better the classical image of the Western liberal state, it is also true that this is a straightjacket for many political societies. The world needs other models to be legitimated in order to allow for more humane and less constraining modes of political cohabitation" (DV 183). Examples of regions in need of such a solution are too numerous to need mention.

Speculating about the role of political institutions in society, Taylor supports the principle of diversity in another respect: he proposes that political life and the form it takes, rather than being limited to the performance of a public service, can also play a part in securing unity and defining a communal identity. "The definition of the national identity of Quebeckers," he holds, can 
be (at least in part) a function of the democratic character of their political life, by the fact that "the nation's prime ground of agreement will be the fair and honest contest between different tendencies aspiring to determine the community's goals."13 The same principle can be applied at a higher organizational level to Canada at large, or to any other multinational polity. Taylor restates it in an interesting way that, I think, takes us a step beyond "deep diversity." In place of "a national life presuming unanimity," he proposes an alternative "ideal type" of national identity, "a national life founded on diversity, in which the political process takes on a crucial significance, not only as an instrument of selfdefinition but as a major component of a national identity, which is largely constituted by debate, without definitive closure, between a plurality of legitimate options" (RS 132). This is Taylor's vision of "politics as the way of life of free citizens" (RS 131). Applied to Canada as a whole, the concept of "debate without definitive closure" opens up the possibility of a polity that provides for its own evolution, for the kind of "evolving Canadian federation" for which Ittinuar hopes.

A political life founded on diversity, in which each member of the federation would be free to evolve its own form of selfgovernance, would embody the kind of "politics of recognition" Taylor repeatedly advocates. It is consonant, not only with Canadian aboriginal rights as officially defined, but also with what Boldt and Long hold to be the aspiration of most native peoples:

Most Indian peoples are committed to a separate social system with corresponding networks of social institutions that are congruent with their historical tribal arrangements and that are based on their traditional identity, language, religion, philosophy, and customs. The Canadian government is ready to accept Indian self-government. The challenge for Indian leaders is to develop a model of self-government that is acceptable to the Canadian government and that gives Indians internal self-determination without compromising fundamental traditional values. The option of pluralism suggests itself [TT 342].

Among these traditional values is direct participatory democracy and rule by consensus. While majority rule might still be the norm in Canada at large, indigenous tribes could still govern 
themselves internally in their traditional way, in which "the people ruled collectively, exercising authority as one body with undivided power, performing all functions of government" (TT 337). ${ }^{14}$

In Home and Native Land, Michael Asch advocates a version of "consociationism," a concept of political pluralism explored independently by two different Western thinkers, Arend Lijphart and M. G. Smith, and versions of which are typified by Belgium and Switzerland..$^{15}$ Holding that it is possible to incorporate such a system within the Canadian political state, Asch maintains that it can accommodate both "the aboriginal fact" and "the French fact" (HNL 82). It is also in line with the expressed views of the Assembly of First Nations, which include

a division of responsibilities between a national and a segmental level; a land base upon which to establish the legislative authority deemed essential to insure the autonomous development of the segment; the protection of segmental rights through the introduction of a veto over changes that otherwise might be imposed by the other segments of the population; and some degree of proportionality in representation. As such, it is a position that reflects, in its specific goals as well as in its overall orientation, consistency with the principles of consecration ... [HNL 89].

Proportional representation is one way to ensure that the interests of the smaller aboriginal nations are taken into account. Protection of each nation's land base is especially important because of the close association in aboriginal thought between identity, community, and location. As Paul Tennant puts it, in his article in The Quest for Justice,

In keeping with aboriginal philosophy, Indian claims are invariably advanced on behalf of the community. Indians take the position that their claims to land and self-government do not depend on racial criteria or particular cultural elements, but rather on the existence of their communities from time immemorial. . .

'Place' is the key element; it implies and includes the claim to continued functioning of the community in that place, and selfgovernment is a key function of this functioning. ${ }^{16}$

The most important element in consociational democracy, Asch points out, is that "citizenship presumes identification with one 
or the other of the primary ethnonational collectivities . . . each [of which] bears coordinate status" (HNL 78). (Taylor's model would conform if all the collectivities had comparable status.)

Comparing aboriginal designs for self-governance and relating them to the consociational view, Asch finds two main groups of proposals. Those of the southern tribes, who are minorities in their areas, are much closer to the "direct" consociational model exemplified by Belgium: selected areas of jurisdiction would, through explicit legislation, be placed under segmental control ("direct entrenchment"). "That is, the ethnonational political rights of the aboriginal peoples would be specified and guaranteed to a named ethnonational entity: the aboriginal peoples of Canada." However, "it is anticipated that whereas the powers to be acquired through entrenchment will be specified, different groups will shape their institutions of government in different ways" (HNL 90, 91-92).

The northern peoples, reflecting the fact that each constitutes a majority or near majority of the population of its home territory, have called for two separate, self-governing jurisdictions, Nunavut and Denendeh, each with power over its own culture and resources. But their proposals, too, differ from one another. The Inuit proposal for Nunavut is much more like the present provincial governments and closer to the "indirect" consociational model, relying on the vote of all the citizens. This was expressed by the Nunavut Constitutional Forum in 1983: "Nunavut is 'public government'. That is, it is a government for all the people who live in the area embraced by Nunavut whether they were born in Igloolik or Trois Rivières, Lloydminster or Yellowknife. Nunavut is not a government only for Inuit, but a government firmly founded on the Canadian political tradition of public services and the power of participation for all people who live in a geographical area" (HNL 94).

Nevertheless, according to the same document, the Nunavut government would "provide specific guarantees for Inuit in respect of certain of their vital interests. . . Nunavut will not only be a provincial-type government, but also the homeland of the distinct and ancient Inuit culture," with a special role in protecting the Inuit heritage (HNL 94). The Dene and Metis proposal for Denendeh would accomplish a similar end by means of a 
Charter of Founding Principles, which would provide for "the right of the Dene (and other citizens) to 'establish government funded institutions and services to reflect their respective values and ways, in such areas as education, health services, and social services" " (HNL 98, 97). And, to protect their majority status, since outsiders tend to come to the Northwest Territories for relatively short periods in connection with employment, both nations would impose a longer residency requirement for voting than the other provinces do (HNL 102-103).

That Taylor's proposal for a federalism based on deep diversity would, in the main, be found congenial by these writers seems likely. However, concerning all the ideas considered here, let me paraphrase Asch's conclusion regarding the proposals for Nunavut and Denendeh: "Although they are foreign to our traditional political culture, [they do not seem] to produce a situation that is at variance with our fundamental political values"; but they require "a degree of flexibility in organizing institutions of government" beyond what anyone has yet achieved (HNL 104).

\section{Notes}

1. Will Kymlicka, Liberalism, Community, and Culture (Oxford: Clarendon Press, 1989). In his more recent book, Multicultural Citizenship: A Liberal Theory of Minority Rights (Oxford: Oxford University Press, 1995), he cites a paper, "Native Rights as Collective Rights: A Question of Group Self-Preservation," Canadian Journal of Law and Jurisprudence, 2, No. 1 (1989), by an aboriginal philosopher, Darlene M. Johnston, in a note on the concept of collective rights, identifying it as representative of "the 'communitarian' camp" (p. 207n20). This paper is included in the anthology Kymlicka edited, The Rights of Minority Cultures (Oxford: Oxford University Press, 1995), pp. 179-201.

2. Charles Taylor, "Shared and Divergent Values" (1991) in Reconciling the Solitudes: Essays on Canadian Federalism and Nationalism, ed. Guy LaForest (Montreal and Kingston: McGill-Queens University Press, 1993), p. 184. Hereafter, the chapter will be cited as DV; the volume, which is a collection of independent papers and addresses, as RS.

3. The Quest for Justice: Aboriginal Peoples and Aboriginal Rights, ed. Menno Boldt and J. Anthony Long, in association with Leroy Little Bear (Toronto: University of Toronto Press, 1985); hereafter cited as QJ. 
4. Michael Asch, Home and Native Land: Aboriginal Rights and the Canadian Constitution (Vancouver: University of British Columbia Press, 1993); hereafter cited as HNL. Another writer who takes the views of aboriginals into account is Allan McChesney; see his "Aboriginal Communities, Aboriginal Rights, and the Human Rights System in Canada," in Human Rights in Cross-Cultural Perspective: A Quest for Consensus, ed. Abdullah Ahmed An-Na'im (Philadelphia: University of Pennsylvania Press, 1992).

5. The Assembly of First Nations represents reservation Indians; offreservation Indians are represented by the Native Council of Canada.

6. Menno Boldt and J. Anthony Long, "Tribal Traditions and European-Western Political Ideologies: The Dilemma of Canada's Native Indians" (QJ 333); hereafter cited as TT.

7. Fred Plain, "A Treatise on the Rights of the Aboriginal Peoples of the Continent of North America" (QJ 32).

8. Peter Ittinuar, "The Inuit Perspective on Aboriginal Rights" (QJ 47). Metis are of mixed Indian and non-Indian heritage.

9. Taylor, "The Stakes of Constitutional Reform" (1990), RS 150; hereafter cited as CR.

10. Cf. Kymlicka's contention that differential citizenship rights may be needed in culturally plural societies, Chapter 6, p. 103 above.

11. 'Enfranchisement' has a special usage in Canada, unrelated to the vote: 'The term 'enfranchisement' is another misnomer perpetuated by the Indian Act. Indians can vote in all elections in Canada [since 1960]. Termination of status does not alter voting rights" (Douglas Sanders, "The Bill of Rights and Indian Status," University of British Columbia Law Review, 7, No. 1 [1965], 94n6).

12. Pertaining only to selected groups, these are not rights in my sense of the term.

13. Taylor, "Institutions in National Life" (1988) (RS 130).

14. Boldt and Long acknowledge the fact that this concept is incon$\rightarrow$ sistent with the European notion of sovereignty, with its sharp distinction between the ruler and the ruled (TT 337).

15. Arend Lijphart, Democracy in Plural Societies (New Haven, Connecticut: Yale University Press, 1977); M. G. Smith, "Some Developments in the Analytic Framework of Pluralism," in Pluralism in Africa, ed. Leo Kuper and M. G. Smith (Berkeley: University of California Press, 1969), pp. 415-458.

16. Paul Tennant, "Aboriginal Rights and the Penner Report on Indian Self-Government” (QJ 324). 
